\title{
Salt stress alters DNA methylation levels in alfalfa (Medicago spp)
}

\author{
A. Al-Lawati ${ }^{1}$, S. Al-Bahry ${ }^{1}$, R. Victor ${ }^{1}$, A.H. Al-Lawati ${ }^{2}$ and M.W. Yaish ${ }^{1}$ \\ 1'Department of Biology, College of Science, Sultan Qaboos University, Alkhuod, \\ Muscat, Oman \\ ${ }^{2}$ Oman Animal and Plant Genetic Resources Center, The Research Council, \\ Muscat, Oman \\ Corresponding author: M.W. Yaish \\ E-mail: myaish@squ.edu.om \\ Genet. Mol. Res. 15 (1): gmr.15018299 \\ Received December 17, 2015 \\ Accepted February 11, 2016 \\ Published February 26, 2016 \\ DOI http://dx.doi.org/10.4238/gmr.15018299
}

ABSTRACT. Modification of DNA methylation status is one of the mechanisms used by plants to adjust gene expression at both the transcriptional and posttranscriptional levels when plants are exposed to suboptimal conditions. Under abiotic stress, different cultivars often show heritable phenotypic variation accompanied by epigenetic polymorphisms at the DNA methylation level. This variation may provide the raw materials for plant breeding programs that aim to enhance abiotic stress tolerance, including salt tolerance. In this study, methylation-sensitive amplified polymorphism (MSAP) analysis was used to assess cytosine methylation levels in alfalfa (Medicago spp) roots exposed to increasing $\mathrm{NaCl}$ concentrations $(0.0,8.0,12.0$, and $20.0 \mathrm{dS} / \mathrm{m})$. Eleven indigenous landraces were analyzed, in addition to a salt-tolerant cultivar that was used as a control. There was a slight increase in DNA methylation upon exposure to high levels of soil salinity. Phylogenetic analysis using MSAP showed epigenetic variation within and between the alfalfa landraces when exposed to saline conditions. Based on MSAP and enzyme-linked immunosorbent assay results, we found that salinity increased global DNA methylation status, particularly in plants exposed to the highest level of 
salinity (20 dS/m). Quantitative reverse transcription-polymerase chain reaction indicated that this might be mediated by the overexpression of methyltransferase homolog genes after exposure to saline conditions. DNA demethylation using 5-azacytidine reduced seedling lengths and dry and fresh weights, indicating a possible decrease in salinity tolerance. These results suggest that salinity affects DNA methylation flexibility.

Key words: Medicago; MSAP; Methylation; Salinity

\section{INTRODUCTION}

Alfalfa (Medicago spp) is a major global perennial legume crop, with an approximate annual production of 60 million metric tons covering about 30 million ha (Monfreda et al., 2008). It is affected by an excessive amount of salt in the soil, which leads to a significant reduction in yield (Rahman et al., 2015). Salinity tolerance level varies between alfalfa varieties and the mechanism of this tolerance is unknown (Peel et al., 2004).

Plant species vary in their tolerance to salinity, which is related to their ability to express genes associated with salinity-tolerance mechanisms. Plant genomes encode various key genes that are involved in salinity-tolerance mechanisms, and their activity is strongly affected by transcriptional and posttranscriptional modifications (Sreenivasulu et al., 2007).

Plants have the ability to control gene expression through various epigenetic events, including histone covalent posttranslational modifications, the production of small RNA or miRNA molecules, and DNA methylation. These events are crucial in adaptation processes when plants are exposed to stressful environmental conditions, including salinity (Yaish et al., 2011).

DNA methylation refers to the addition of a methyl group, mainly to cytosine residues, without changing the DNA double helix sequence. This addition can be flexible, symmetric, or asymmetric, and is catalyzed in plants by a group of methyltransferase enzymes (Chan et al., 2005). For example, in Arabidopsis, DNA methylation is controlled by METHYTRANSFERASE1 (MET1), MET2, and MET3 (Henderson and Jacobsen, 2007), DOMAINS REARRANGED METHYLTRANSFERASE (DRM1/2) and CHROMOMETHYLASE3 (CMT3) (Lindroth et al., 2001), and DNA METHYLATION1 (DDM1) (Kakutani et al., 2004).

DNA methylation is often associated with gene silencing, other chromatin modifications such as histone acetylation (Yaish et al., 2009), and transgenerational epigenetic inheritance (Iwasaki, 2015). DNA methylation is partly controlled by epigenetic machinery (sRNA) through a mechanism known as RNA-directed DNA methylation (Ci et al., 2015). The importance of DNA methylation stems from the fact that it is induced by abiotic stress (Yaish, 2013), and de novo DNA methylation can be inherited through cell division. This is particularly interesting, because DNA methylation may also alter the chromosomal homologous recombination frequency in somatic cells, a process that may lead to genetic variation (Boyko et al., 2010) and the appearance of novel traits. Therefore, there is a fundamental crosstalk between epigenetics, genetic change, and environmental stress in plants.

Genetic and epigenetic polymorphisms are the sources of variation that provide raw materials for breeding programs that aim to improve salinity stress tolerance in plants. This variation can be detected by developing suitable molecular genetic and epigenetic markers associated with salinity tolerance (Wang et al., 2015b). The construction of genetic maps using DNA markers and the localization of quantitative trait loci are routine practices in breeding programs. However, recent 
studies have reported that polymorphic epigenetic markers based on the presence of polymorphic epialleles (Kakutani, 2002) can be used to construct a DNA methylation-based map known as a methylome (Zhong et al., 2013).

In order to understand the potential role of DNA methylation changes in gene regulation and salinity tolerance in alfalfa, we analyzed epigenetic relationships based on DNA methylation levels in the presence and absence of salinity stress using the methylation-sensitive amplified polymorphism (MSAP) method. The effect of methylation on salinity stress tolerance was also studied. The MSAP analysis showed that high salinity increased DNA methylation and resulted in higher DNA methylation diversity than genetic diversity in the alfalfa genotypes studied.

\section{MATERIAL AND METHODS}

\section{Growth conditions and plant treatments}

Seeds from 11 local landraces of Medicago sativa and an Australian Medicago truncatula (Caliph Medic) (Table 1) were surface-sterilized and grown in 5-L pots containing a mixture of vermiculite and peat moss $(2: 1)$ until they reached the adult stage prior to flowering. The pots were incubated in a greenhouse under natural light/dark conditions, and the mean temperature was set at $30^{\circ}$ and $25^{\circ} \mathrm{C}$ during day and night, respectively. Plants were either irrigated with distilled water or with saline solution $(8,12$, or $20 \mathrm{dS} / \mathrm{m})$ for 1 week.

Table 1. Regional distribution of the indigenous alfalfa landraces used in this study.

\begin{tabular}{l|l|l|c|c}
\hline Accession & Region & Village & Latitude (N) & Longitude (E) \\
\hline MS9 & Nizwa & Tanouf & $23^{\circ} 02.00^{\prime}$ & $57^{\circ} 43.45^{\prime}$ \\
\hline MS88 & Ibri & Bat & $23^{\circ} 15.22^{\prime}$ & $56^{\circ} 45.23^{\prime}$ \\
\hline MS95 & Ibri & Al-Ablaah & $23^{\circ} 04.84^{\prime}$ & $56^{\circ} 54.14^{\prime}$ \\
\hline MS148 & Rustaq & Azammah & $23^{\circ} 13.48^{\prime}$ & $57^{\circ} 24.79^{\prime}$ \\
\hline MS195 & Nakhal & Alqoorah & $23^{\circ} 05.38^{\prime}$ & $57^{\circ} 44.20^{\prime}$ \\
\hline MS220 & Bahla & Tawee A Nuseif & $22^{\circ} 57.66^{\prime}$ & $57^{\circ} 12.63^{\prime}$ \\
\hline MS234 & Hamasah & $24^{\circ} 14.78^{\prime}$ & $55^{\circ} 46.14^{\prime}$ \\
\hline MS238 & Buraimi & $24^{\circ} 54.35^{\prime}$ & $55^{\circ} 50.55^{\prime}$ \\
\hline MS279 & Mahdah & Mukteebyyah & $22^{\circ} 39.25^{\prime}$ & $58^{\circ} 41.13^{\prime}$ \\
\hline MS290 & Al-Qabel & Bateen & $22^{\circ} 36.13^{\prime}$ & $59^{\circ} 04.48^{\prime}$ \\
\hline MS302 & Wadi Bani Khalid & Al-Raaki & $22^{\circ} 46.59^{\prime}$ & $58^{\circ} 31.24^{\prime}$ \\
\hline
\end{tabular}

\section{MSAP analysis}

The roots were thoroughly washed with tap water, dried, and flash frozen in liquid nitrogen. For each salinity treatment, DNA was extracted from the roots of 10 plants using a DNeasy ${ }^{\circledR}$ Plant Maxi Kit (Qiagen) according to the manufacturer instructions. The MSAP technique was conducted according to the amplified fragment length polymorphism (AFLP) procedure described by Vos et al. (1995), with some modifications (Yaish et al., 2014). Hpall and Mspl methylation-sensitive isoschizomers were used for the MSAP analysis. Both Hpall and Mspl recognize the same tetranucleotide sequence (5'-CCGG-3'), but exhibit differential sensitivity to DNA methylation. While Mspl and Hpall are both sensitive to methylated external cytosine in the sequence CCGG, only Mspl can cleave the sequence when the internal cytosine residue is methylated. Unlike Mspl, Hpall is inactive when any of the two cytosines are fully methylated (both strands methylated), but cleaves the hemi-methylated sites. A total of $100 \mathrm{ng}$ DNA was digested with $12 \mathrm{U}$ EcoRI and $8 \mathrm{U}$ Mspl or Hpall (Fermentas, Germany) at $37^{\circ} \mathrm{C}$ for $3 \mathrm{~h}$. The restriction enzymes were deactivated by 
heating at $70^{\circ} \mathrm{C}$ for $15 \mathrm{~min}$. EcoRI and Mspl or Hpall adaptors (Table 2) were then ligated to the restricted fragments with $1 \cup \mathrm{T} 4 \mathrm{DNA}$ ligase, and incubated overnight at $37^{\circ} \mathrm{C}$. The ligation mixture was diluted 10 -fold by adding $5 \mu \mathrm{L}$ ligation mixture to $45 \mu \mathrm{L}$ water. Pre-selective amplification was conducted in a $25-\mu \mathrm{L}$ reaction volume with the following components: AFLP primer pair, core mix (Applied Biosystems), diluted restriction ligation DNA, and puReTaq ${ }^{T M}$ Ready-To-Go ${ }^{T M}$ polymerase chain reaction (PCR) Beads (Amersham Biosciences). The pre-selective amplification was performed using an Eppendorf gradient thermocycler (Eppendorf, Hamburg, Germany) under the following temperature-cycling conditions: one cycle at $72^{\circ} \mathrm{C}$ for $30 \mathrm{~s} ; 30$ cycles at $94^{\circ} \mathrm{C}$ for $30 \mathrm{~s}$, $56^{\circ} \mathrm{C}$ for $30 \mathrm{~s}$, and $72^{\circ} \mathrm{C}$ for $60 \mathrm{~s}$ with one cycle increase; and finally one cycle at $72^{\circ} \mathrm{C}$ for $2 \mathrm{~min}$. A $10-\mu \mathrm{L}$ aliquot of the pre-selective amplification products was run on a $1.5 \%$ agarose gel with a 100-bp DNA ladder to determine the size of the amplified products. A second PCR round was conducted by selectively amplifying DNA using four primer combinations to generate an MSAP fingerprint. A negative control was included with each primer pair. The PCR conditions were as follows: 13 cycles at $95^{\circ} \mathrm{C}$ for $30 \mathrm{~s}, 65^{\circ} \mathrm{C}$ for $30 \mathrm{~s}, 72^{\circ} \mathrm{C}$ for $60 \mathrm{~s} ; 23$ cycles at $94^{\circ} \mathrm{C}$ for $30 \mathrm{~s}, 56^{\circ} \mathrm{C}$ for $30 \mathrm{~s}, 72^{\circ} \mathrm{C}$ for $60 \mathrm{~s}$; and one cycle at $72^{\circ} \mathrm{C}$ for $60 \mathrm{~s}$.

Table 2. Primers and adaptors used in the methylation-sensitive amplified polymorphism analysis.

\begin{tabular}{l|l}
\hline Adapters & Sequence $\left(5^{\prime}-3^{\prime}\right)$ \\
\hline EcoRl & CTCGTAGACTGCGTACC \\
\hline & AATTGGTACGCAGTCTAC \\
\hline$M s p l$ & CGAGCAGGACTCATGA \\
\hline Pre-selective primers & \\
\hline$E c o R l$ & GACTGCGTACCAATTC \\
\hline$M s p l$ & ATCATGAGTCCTGCTCGG \\
\hline Selective primers & \\
\hline EcoRl & GACTGCGTACCAATTC-AAC \\
\hline Labeled Selective Primers, labeled with WellRed D4 & GACTGCGTACCAATTC-ACC \\
\hline & GACTGCGTACCAATTC-ACA \\
\hline$M s p l$ & GACTGCGTACCAATTC-AAG \\
\hline Hpall & ATCATGAGTCCTGCTCGGTCCA \\
\hline
\end{tabular}

\section{Scoring raw data and statistical analysis}

Detection of MSAP bands was performed using a Beckman Coulter CEQ ${ }^{\text {TM }} 8000$ automated DNA sequencer (Beckman Coulter, Fullerton, CA, USA). Control samples were included in each run in order to ensure the repeatability and accuracy of the results. The raw data obtained were analyzed using the numerical taxonomic and multivariate analysis system (NTSYS-pc) software (Rohlf, 1998). Band matching was performed with a $1 \%$ optimization parameter and a $1 \%$ band tolerance. Only 50-bp or longer PCR products were considered for analysis. Amplified fragments (bands) were generated using four primer combinations, and were manually scored for their presence (1) or absence (0).

\section{5-azacytidine (5-AzaC) treatment}

The seeds were grown for 4 weeks on Petri dishes on filter paper saturated with 50, 100, 200 , or $400 \mathrm{mM} \mathrm{NaCl}$ solutions, either in the presence or absence of $50 \mu \mathrm{M} \mathrm{5-AzaC}$. The growth parameters (lengths and fresh and dry weights) of at least 12 seedlings were measured, and differences between the landraces were considered indications of variation in salinity tolerance. 
To compare the effect of 5-AzaC on growth parameters of the seedlings under control and experimental conditions, a single-factor analysis of variance (ANOVA) was performed. If a significant difference $(P<0.05)$ was detected by the ANOVA, a post hoc Tukey test was performed to determine the nature of the significant difference. These analyses were performed on all 12 genotypes. Regression analyses were only performed on the log-transformed data of two chosen genotypes, in order to investigate relationships between salinity concentrations and growth parameters. These analyses were repeated to investigate relationships between salinity concentrations, 5-AzaC, and the growth parameters of the same two genotypes. As the regression coefficients for salinities with and without 5 -AzaC were always significant $(P<0.05)$, Student $t$-tests assuming equal variances were performed to identify differences between pairs of points on the two best lines of fit (e.g., growth parameter = length; compare performances with $50 \mathrm{mM} \mathrm{NaCl}$ only and $50 \mathrm{mM} \mathrm{NaCl}$ with $5-\mathrm{AzaC}$ ), so that the salinity concentration at which demethylation had an effect on growth performance could be located.

\section{Estimation of global methylated DNA}

Global DNA methylation was measured using the enzyme-linked immunosorbent assay (ELISA) technique using an Imprint ${ }^{\circledR}$ Methylated DNA Quantification Kit (Sigma). Equal amounts of DNA samples extracted from the roots of the control and salinity-treated plants $(8,10,12$, or 20 $\mathrm{dS} / \mathrm{m}$ ) were used in the reaction, following the manufacturer instructions. Four biological replicates were used in the assay.

\section{Identification of MSAP products}

Selective PCRs of high MSAP bands were subjected to $15 \%$ sodium dodecyl sulfate polyacrylamide gel electrophoresis. Subsequently, the gels were stained with ethidium bromide and the MSAP bands were excised from the gels and purified using a gel extraction kit (Qiagen). The purified DNA fragments were cloned into a pGEM ${ }^{\circledR}-T$ Easy Vector (Promega) and transferred to DH10B Escherichia coli-competent cells. Positive plasmids were sequenced using a T7 primer, and the resultant sequences were BLAST-searched against the available DNA sequences in GenBank.

\section{Determination of methyltransferase homolog expression levels}

The expression levels of two DNA methyltransferase homologs (MTR_4g035150 and MTR_6g065580) were quantified using quantitative reverse transcription-PCR (qRT-PCR). Total RNA was extracted from the roots of a pool of five plants treated with a $20-\mathrm{dS} / \mathrm{m}$ salt solution and five untreated plants. cDNA was synthesized using a High-Capacity cDNA Reverse Transcription Kit (Life Technologies, USA). The qRT-PCR for MTR_4g035150 was conducted using the primers MTR_4g035150F (5'-CAAGAAGTTGCCAGCACATA-3') and MTR_4g035150R (5'-GAAACACCA GACTGATGCAA-3'), and for MTR_6g065580, MTR_6g065580F (5'-TGCAAGAGGTGTATTACA GTGA-3') and MTR_6g065580 R (5'-ATATTATGGAAGATTCCGGG-3') were used. A Fast SYBR ${ }^{\circledR}$ Green Master Mix Kit (Life Technologies) and the $2^{-\triangle \Delta C T}$ method for relative quantifications were used. The M. truncatula mRNA actin sequence (GenBank accession No. JQ028731) was used as a housekeeping normalization gene, using forward MtactinF (5'-TTCTCTCAGTACTTTCCAGC-3') and reverse MtactinR (5'-AAGCATCACAATCACTCC-3') primers as described previously (Banasiak et al., 2013). 


\section{RESULTS}

\section{Salinity stress increases the number of methylated loci in alfalfa}

The mean salinity level, measured as the electrical conductivity of the soil, before treatment was $9.1 \mathrm{dS} / \mathrm{m}$. However, after salt treatment, the mean electrical conductivity rose to 15.4, 27.4, and $45.7 \mathrm{dS} / \mathrm{m}$ in the soils watered with solutions of 8,12 , and $20 \mathrm{dS} / \mathrm{m}$, respectively. Epigenetic relationships between the alfalfa landraces were investigated using DNA extracted from the roots of adult plants that had been watered with different levels of saline (Table 1). Epigenetic variations in response to salinity stress were measured based on changes in DNA methylation using MSAP and eight primer combinations (Table 2). The MSAP analysis revealed the presence of 191 reliable polymorphic DNA loci (Table S1), and each variety had between 6 and 25 polymorphic bands. The mean number of polymorphic bands was 14 for each primer combination, and all of the primer combinations had a similar polymorphic information content value of around 0.7 (Table 3).

Table 3. Number of generated bands and the polymorphic information content (PIC) of eight primer combinations in 12 alfalfa landraces.

\begin{tabular}{l|c|c|c|c}
\hline Primer combination & Alleles/locus & PIC value & \% Polymorphic bands & Polymorphic band/cultivar \\
\hline AAC/CCA & 404 & 0.75 & 75 & 25.0 \\
\hline AAC/CAA & 125 & 0.73 & 73 & 7.6 \\
\hline AAG/CCA & 344 & 0.75 & 75 & 21.5 \\
\hline AAG/CAA & 122 & 0.74 & 74 & 7.5 \\
\hline ACA/CCA & 318 & 0.75 & 75 & 79.8 \\
\hline ACA/CAA & 134 & 0.73 & 73 & 8.0 \\
\hline ACC/CCA & 251 & 0.75 & 73 & 15.7 \\
\hline ACC/CAA & 96 & 0.73 & 74 & 5.8 \\
\hline Mean & 224 & 0.74 & & 14.0 \\
\hline
\end{tabular}

Because high $\mathrm{NaCl}$ concentrations have significant effects on plants at the physiological and biochemical levels, our comparative analysis mainly focused on plants treated with the highest $\mathrm{NaCl}$ concentration $(20 \mathrm{dS} / \mathrm{m})$ and the corresponding control treatment. The epigenomic profiles generated using the MSAP method and calculated based on the presence or absence of a PCR fragment revealed differences in DNA methylation levels between the landraces, which were reduced in response to salinity stress.

A cluster analysis based on the di-methylation-sensitive Hapll and Mspl endonucleases and the simple matching coefficient (Halldén et al., 1994) revealed that the alfalfa landraces exhibited greater DNA methylation dissimilarity when grown under $20 \mathrm{dS} / \mathrm{m}$ (Figure 1).

The similarity coefficient between the landraces was obtained based on the presence or absence of a polymorphic fragment when Hapll and Mspl were used. The mean similarity coefficient between landraces grown under control conditions was $0.78 \pm 0.06$ (SD). The highest similarity obtained was between the Ms95 and MtCm landraces (0.92), while the lowest was between Ms234 and Ms88 (0.67) (Figure 2A and Table S2-A).

Of the plants watered with a $20-\mathrm{dS} / \mathrm{m}$ solution, the mean similarity coefficient between the landraces increased to $0.90 \pm 0.04$, and six landraces were clustered in three nodes in the phylogenetic tree. The highest similarity coefficient was between Ms95 and Ms234 (0.97), while the lowest was between Ms290 and MtCm (0.81) (Figure 2B, Table S2-B, and Table 4). The mean genetic variation as indicated by the MSAP loci produced by Mspl was not significantly different between the two treatments $(P \geq 0.05)$ (Figure 1). However, there were high levels of variation between the landraces, as indicated by the standard errors of the means of the similarity 
coefficients (Figure 1). These results suggest that there was a more similar number of methylated DNA sites than hemi-methylated sites in the landraces when exposed to salinity stress. In order to investigate the effect of the high-salinity treatment on the landraces in terms of DNA methylation changes based on the Hpall and Mspl-MSAP markers, the topologies of two phylogenetic trees that were constructed using salt-treated and untreated plants were compared.

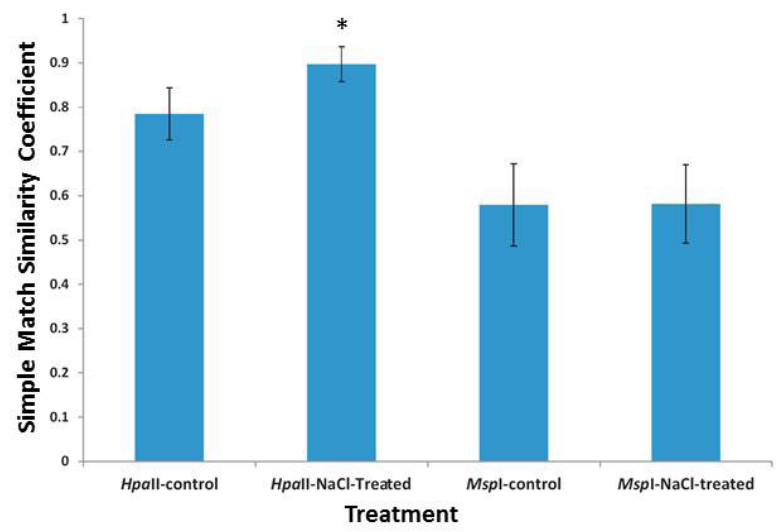

Figure 1. Simple match coefficient variation among 11 alfalfa landraces grown under control and 20-dS/m salinity conditions. Bars represent means $\pm \mathrm{SE}(\mathrm{N}=12)$. Significant differences between the control and $\mathrm{NaCl}$ treatments are indicated with asterisk $(P \leq 0.05)$.

A
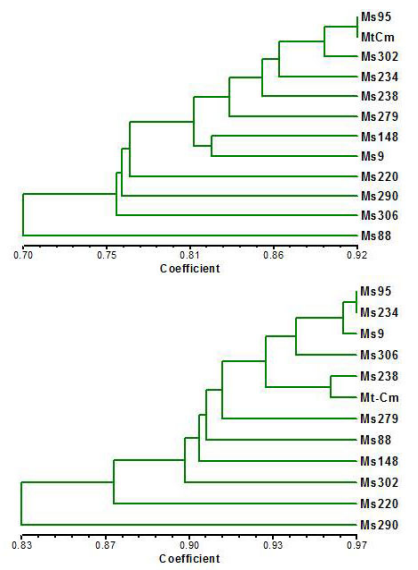

c

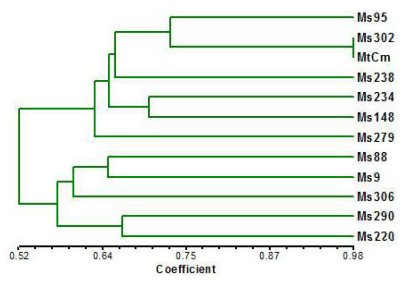

Figure 2. Dendrograms illustrating the phylogenetic relationships between alfalfa landraces based on the methylationsensitive amplified polymorphism markers generated using the methylation-sensitive Hpall endonuclease and DNA extracted from untreated control plants $(\mathbf{A})$, saline treatment $(20 \mathrm{dS} / \mathrm{m})(B)$, and $\mathrm{Mspl}$ endonuclease and untreated control plants (C). 
The optimum match map between branches in terms of a topological score between the two trees (salinity vs control) was obtained by a pairwise comparison of each branch in one dendrogram with the corresponding branch in a second dendrogram using the Compare2Trees software (Nye et al., 2006). The overall topology scores were 61.1 and $100 \%$ when the two trees were constructed using Hpall and $\mathrm{Mspl}$, respectively (Figure 3). These results suggest that high salinity stress significantly alters overall DNA methylation in alfalfa.

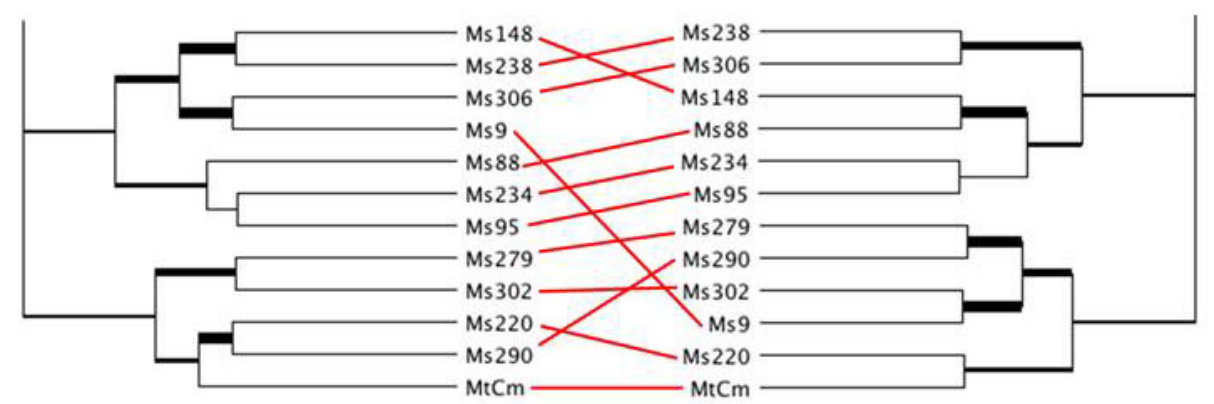

Figure 3. Pairwise comparison of two phylogenetic trees constructed using methylation-sensitive amplified polymorphism markers generated using Hpall endonuclease and DNA extracted from the roots of control (left) and saline-treated (20 dS/m) alfalfa plants (right).

Table 4. Similarity coefficients based on methylation-sensitive amplified polymorphism data from saline-treated $(20 \mathrm{dS} / \mathrm{m})$ and untreated (control) DNA extracted from alfalfa roots.

\begin{tabular}{l|c|c|c}
\hline & Mean & Max. & Min. \\
\hline Hpall-control & 0.784794 & 0.916 & 0.67 \\
\hline Hpall-treated & 0.896879 & 0.969 & 0.812 \\
\hline Mspl-control & 0.579273 & 0.984 & 0.435 \\
\hline Mspl-treated & 0.581242 & 0.958 & 0.435 \\
\hline
\end{tabular}

Based on the MSAP at the 5'-CCGG-3' sites, a DNA fragment produced by the analysis was classified as a non-methylated CpG locus if it was not polymorphic, a methylated CpG locus in the presence of EcoRI/Mspl digestion fragments and absence of EcoRI/Hpall digestion fragments, or a hemi-methylated CpG locus in the absence of EcoRI/Mspl digestion fragments and presence of EcoRI/Hpall digestion fragments at the same locus (Peraza-Echeverria et al., 2001; Salmon et al., 2008; Lira-Medeiros et al., 2010). Differential methylation analysis using EcoRI/Mspl and EcoRI/Hpall revealed the presence of non-methylated, methylated, and hemi-methylated loci in the landraces, and the appearance of de novo loci upon irrigation with four different concentrations of saline solutions $(4,8,12$, or $20 \mathrm{dS} / \mathrm{m})$. A total of 11,449 fragments were generated from the 12 landraces grown under control and different-salinity conditions (Table S3 $)$. A total of $10 \%$ of the loci were non-methylated (Table S3-A), 70\% were methylated (Table S3-B), and 20\% were hemimethylated (Table S3-C). The mean numbers of methylated loci per cultivar under the control and 20-dS/m saline conditions were 157 and 176, respectively (Figure 4 and Table S3-A), the mean numbers of non-methylated loci were 35 and 13, respectively (Figure 4 and Table S2-B), and the mean numbers of hemi-methylated loci were 60 and 35, respectively (Figure 4 and Table S2-C). Salinity treatment significantly affected methylation status in the roots, particularly in the highest 
$\mathrm{NaCl}$ concentration $(20 \mathrm{dS} / \mathrm{m})$ treatment. While the number of non-methylated and hemi-methylated loci significantly decreased, the number of methylated loci increased (Figure 4). After irrigation with a saline solution, DNA methylation levels changed significantly $(P \leq 0.05)$. For example, in plants watered with the $20-\mathrm{dS} / \mathrm{m} \mathrm{NaCl}$ solution, the mean number of non-methylated loci per cultivar decreased by $63 \%$, the mean number of methylated loci increased by $12 \%$, and the mean number of hemi-methylated loci decreased by $42 \%$, in comparison with the control treatment (Figure 4 ).

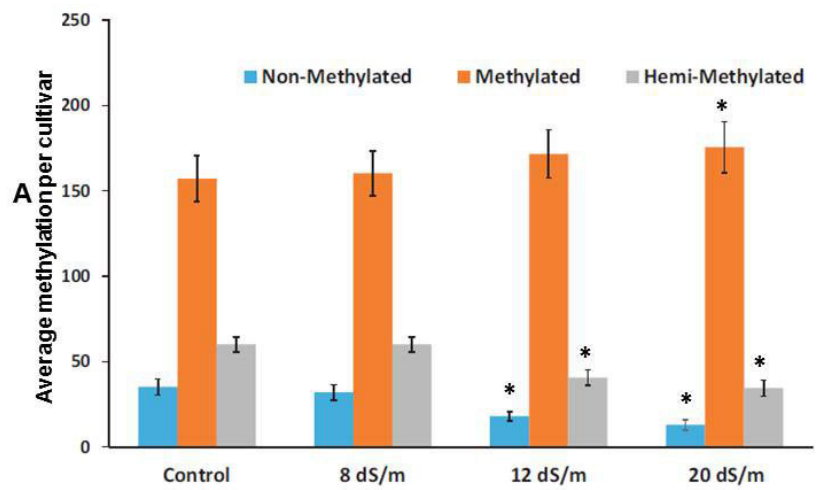

Figure 4. Effect of salinity stress on the level of DNA methylation at the 5'-CCGG-3' site, demonstrated as mean methylation per cultivar. Bars represent means $\pm S E(N=12$ genotypes). Significant differences between the control and $\mathrm{NaCl}$ treatments are indicated with asterisks $(\mathrm{P} \leq 0.05)$.

\section{High soil salinity promotes global DNA methylation}

An ELISA was used to measure global DNA methylation changes in the M. truncatula (Caliph Medic) cultivar upon exposure to different levels of salinity stress. In comparison with untreated plants (irrigated with distilled water), there were slight increases of 1 and $2 \%$ in the estimated amount of global DNA methylation in plants irrigated with 8- and 12-dS/m solutions, respectively. There was a significant increase of $26 \pm 0.01 \%$ (mean \pm SE) in global DNA methylation levels in plants irrigated with the $20-\mathrm{dS} / \mathrm{m}$ solution $(\mathrm{P} \leq 0.05)$ (Figure 5$)$.

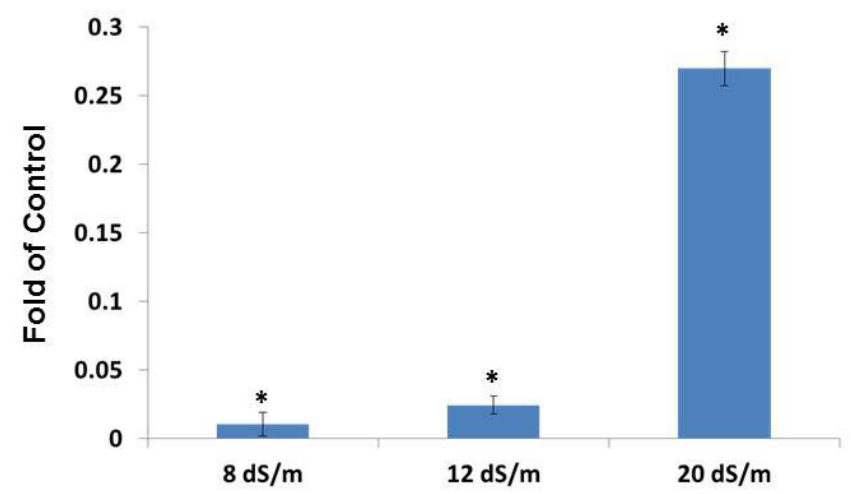

Figure 5. Global DNA methylation changes in comparison with untreated plants (control) measured in root tissues of the $\mathrm{MtCm}$ genotype. Bars represent means of biological replicates $\pm \mathrm{SE}(\mathrm{N}=4)$. Significant differences between the control and $\mathrm{NaCl}$ treatments are indicated with asterisks $(P \leq 0.05)$. 


\section{Sequencing the MSAP DNA loci}

To identify MSAP DNA fragments and to determine their relationship with salinity-tolerance mechanisms and stress-responsive genes in alfalfa, 20 MSAP DNA fragments were separated on a polyacrylamide gel, cloned into a plasmid, and sequenced. BLAST search results against nucleic and amino acid databases did not find a similarity with genes known to be involved in salinity tolerance, but did reveal some similarities with other DNA sequences cloned from different species. There was some similarity between Beta nana Ty1-copia-like retrotransposon pol pseudogene from $B$. nana to previously isolated microsatellite markers from Musa balbisiana, Citrus reticulata, and Tectona grandis, and to a TX 116 AFLP sequence isolated from Gossypium hirsutum. In addition, some of the cloned DNA fragments were similar to genes cloned from the nitrogen-fixing bacteria Sinorhizobium meliloti, and to the soil-borne plant pathogen fungus, Phytophthora cinnamomi.

\section{Treatment with 5-AzaC reduces salinity tolerance in alfalfa seedlings}

Because fresh weight was significantly different between five genotypes $(P<0.05)$ and indicated large variability between the salinity treatments (Figure 6), it was discarded as an unreliable parameter. Therefore, only length and dry weight were used for studying the inhibition of DNA methylation by 5-AzaC. This screening was also used to select two of the 12 genotypes for further experimentation: Ms 234, which had the worst performance, and the exotic genotype MtCm, which had the best performance.

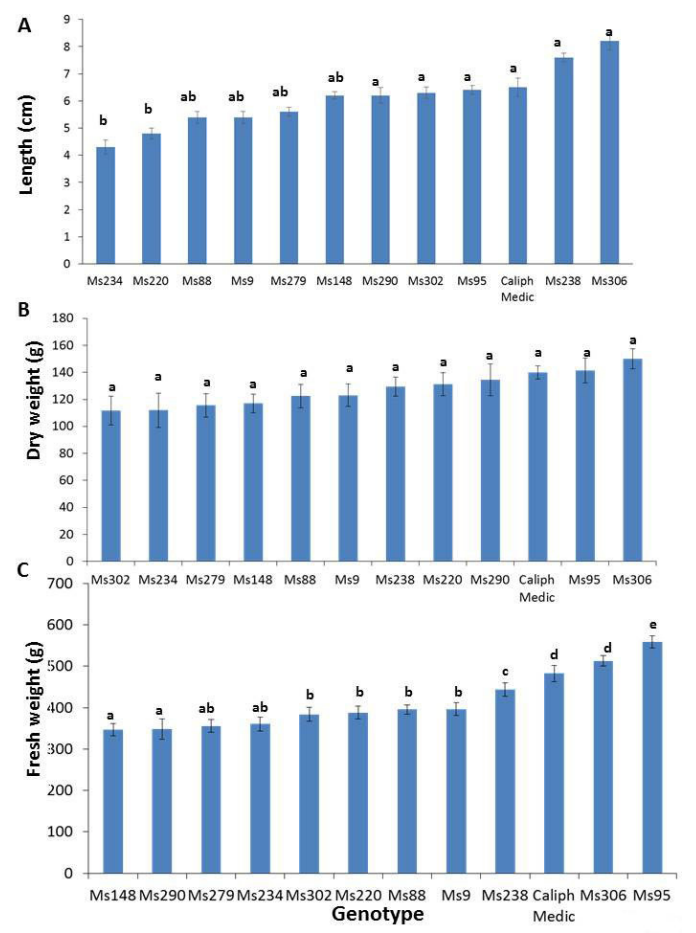

Figure 6. Cultivar vigor measured as seedling length (A), dry weight (B), and fresh weight (C). Bars represent means $\pm S E(N=4)$. Landraces with the same letters were not significantly different $(P \geq 0.05)$. 
The regression analyses revealed that these relationships were significant, and are described by the following equations: length $=-0.6010$ (salinity) $+1.8462, \mathrm{R}^{2}=0.7933$ for $\mathrm{NaCl}$; and length $=-0.4445$ (salinity) $+1.3331, \mathrm{R}^{2}=0.6612$ for $\mathrm{NaCl}+5-\mathrm{AzaC}$. There was a significant reduction in the length of the seedlings with increasing salinity, both for $\mathrm{NaCl}$ and $\mathrm{NaCl}+5-\mathrm{AzaC}$ $(P<0.0001)$. The rates of reduction in length as estimated by the regression coefficients were significantly different between the $\mathrm{NaCl}$ and $\mathrm{NaCl}+5-\mathrm{AzaC}$ treatments $(P<0.05)$. At 50,100 , and $200 \mathrm{mM}$ salinities with or without 5-AzaC, the reductions in length were significantly different $(P<$ 0.05), while at $400 \mathrm{mM}$ salinity, they were not significantly different $(P>0.05)$.

The regression analyses showed that these relationships were significant, and are described by the following equations: dry weight $=-1.9414$ (salinity) $+3.5551, R^{2}=0.7484$ for $\mathrm{NaCl}$; and dry weight $=-2.8150$ (salinity) $+4.8460, \mathrm{R}^{2}=0.8446$ for $\mathrm{NaCl}+5-\mathrm{AzaC}$. There was a significant reduction in the dry weight of the seedlings with increasing salinity, both for $\mathrm{NaCl}$ and $\mathrm{NaCl}+5-\mathrm{AzaC}(\mathrm{P}<0.0001)$. The rates of reduction in dry weight as estimated by regression coefficients were significantly different between the $\mathrm{NaCl}$ and $\mathrm{NaCl}+5-\mathrm{AzaC}$ treatments $(\mathrm{P}<0.05)$.

The dry weight reduction at all concentrations of salinity $(50,100,200$, and $400 \mathrm{mM})$ with and without $5-A z a C$ was significantly different $(P<0.0001)$. These relationships were significant and are described by the following equations: length $=-0.6628$ (salinity) $+1.9298, R^{2}=0.8347$ for $\mathrm{NaCl}$; and length $=-0.7936$ (salinity) $+1.8083, \mathrm{R}^{2}=0.8177$ for $\mathrm{NaCl}+5-\mathrm{AzaC}$ (Figure 7). There was a significant reduction in the length of the seedlings with increasing salinity, both for $\mathrm{NaCl}$ and $\mathrm{NaCl}+5-\mathrm{AzaC}(\mathrm{P}<0.0001)$. The rates of reduction in length as estimated by regression coefficients were significantly different between the $\mathrm{NaCl}$ and $\mathrm{NaCl}+5-\mathrm{AzaC}$ treatments $(\mathrm{P}<0.05)$. Seedling lengths at $200 \mathrm{mM}$ salinity with and without 5-AzaC were not significantly different $(P>$ $0.05)$, but at all other salinities there were significant differences $(P<0.0001)$. These relationships were significant and are described by the following equations: dry weight $=-2.1757$ (salinity) + $3.9480, \mathrm{R}^{2}=0.8665$ for $\mathrm{NaCl}$; and dry weight $=-3.0690$ (salinity) $+5.3117, \mathrm{R}^{2}=0.8870$ for $\mathrm{NaCl}$ +5 -AzaC. There was a significant reduction in dry weight with increasing salinity, both for $\mathrm{NaCl}$ and $\mathrm{NaCl}+5-\mathrm{AzaC}(\mathrm{P}<0.0001)$. The rates of reduction in dry weight as estimated by regression coefficients were significantly different between the $\mathrm{NaCl}$ and $\mathrm{NaCl}+5-\mathrm{AzaC}$ treatments $(\mathrm{P}<0.05)$.
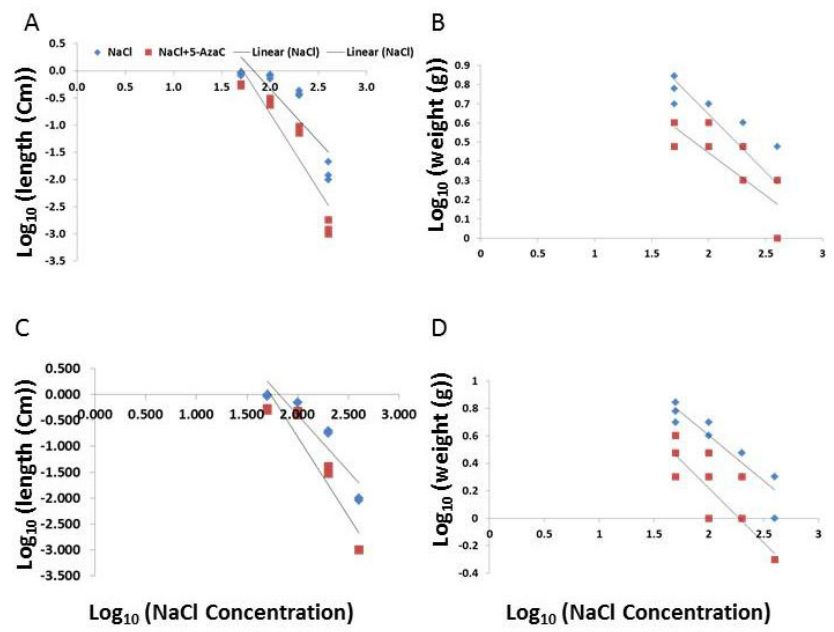

Figure 7. Effect of 5-azacytidine (5-AzaC) on lengths and dry weights of alfalfa seedlings when exposed to 50, 100, 200 , or $400 \mathrm{mM} \mathrm{NaCl}$ in the presence or absence of $50 \mu \mathrm{M}$ 5-AzaC. A. B. MtCm; C. D. Ms 234. 
The dry weight reduction at all concentrations of salinity with and without 5-AzaC was significantly different between the treatments $(P<0.0001)$.

The results show that there was an inverse relationship between $\mathrm{NaCl}$ concentration and the seedling lengths of all of the alfalfa genotypes used in this study. Regression analyses showed that when $50 \mu \mathrm{M} 5$-AzaC was added to the $\mathrm{NaCl}$ solutions, the seedling lengths and fresh weights were further reduced (Figure 7 and Figure S1). The landraces exhibited similar patterns of response to 5-AzaC in terms of seedling length and dry and fresh weight (Figures 7 and $\underline{\mathbf{S 1}}$ ). 5 -AzaC reduced seedling growth in plants grown under no saline (control) conditions, as well as when they were grown under different saline conditions. 5-AzaC had an additive negative effect on growth in seedlings grown in high levels of salinity (Figure 7), but this effect was more obvious when plants were grown under low-salinity conditions. For example, in comparison with the control treatment, 5-AzaC had a greater effect on seedlings grown under no $\mathrm{NaCl}$ conditions than those grown in $400 \mathrm{mM} \mathrm{NaCl}$.

\section{DNA methyltransferase genes induced by salinity stress}

The addition of a methyl group to DNA is controlled by different groups of DNA methyltransferases. Therefore, in order to ascertain why DNA methylation increased in the roots, the expression levels of two DNA methyltransferase homologs were measured. Two mRNA sequences (R4 and R6) that were annotated in the M. truncatula database as DNA methyltransferase homologs were downloaded and used to design qPCR-specific primers. The R4 and R6 expression levels had increased by 5- and 10-fold, respectively (Figure 8).

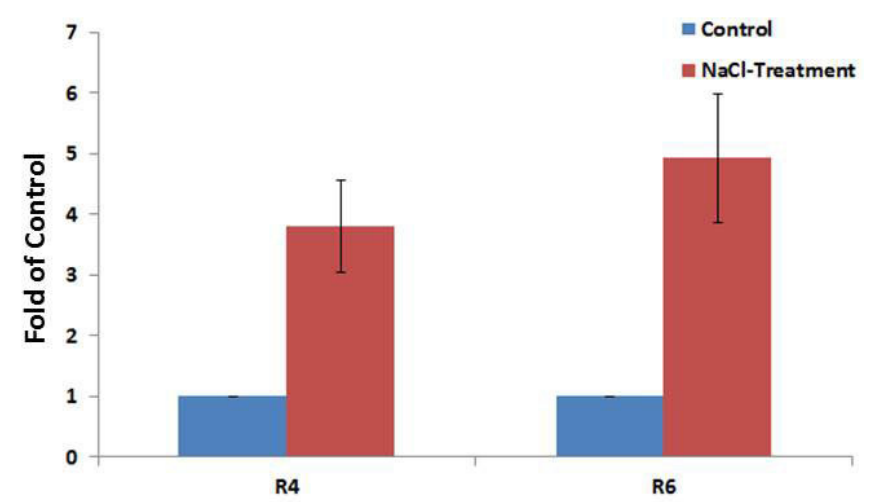

Figure 8. DNA methyltransferase homologs induced by salinity treatment $(400 \mathrm{mM})$. Bars represent means \pm SE $(\mathrm{N}$ $=3$ ) of biological replicates.

\section{DISCUSSION}

Adaptation to abiotic stress in plants requires alterations in the activity of certain genes, often combined with DNA demethylation. Yet, unlike other abiotic stressors, high salinity and water deficiency often enhance DNA methylation in plants (Wang et al., 2015a). We found that salinity stress increased the methylome content of alfalfa plants, particularly when the plants were treated with a $20-\mathrm{dS} / \mathrm{m}$ solution (Figures 4 and 5). An increase in DNA methylation was detected at the CpG level on the 5'-CCGG-3' sites (Figure 4), as well as at the global DNA level (Figure 8). 
Root tissues were selected for DNA methylation analysis because they have a direct interaction with saline soil. This interaction may lead to tissue methylation specificity, which may have an effect on biological processes aimed at tolerating saline conditions (Yaish, 2015; Yaish et al., 2015b). The alteration of DNA methylation levels at the Hpal site in response to the salinity treatments varied among the landraces (Figure 3). This result is in agreement with the widely accepted view that closely related species may possess some methylome flexibility, and consequently gene expression diversity (Postnikova et al., 2013). For example, rice cultivars with different salinity-tolerance capacities exhibit different DNA methylation patterns in response to salinity stress (Ferreira et al., 2015; Garg et al., 2015; Wang et al., 2015b). Overall, the mean number of methylated MSAP loci increased while the number of hemi and non-methylated loci decreased (Figure 4). MSAP loci generated by Hpal revealed a dynamic change in methylation status caused by high salinity, which changed the epigenetic relationship between the landraces (Figure 3). However, hemi-methylation changes among the tested landraces were not detectable when Mspll was used in the MSAP analysis. This demonstrates the effect of salinity stress on the stability of fully methylated loci in alfalfa. Hemi-methylated DNA loci in human cells have a high probability of being methylated in vitro by DNMT1 (Jin et al., 2011). This suggests that hemimethylation could be a transient stage before full methylation.

Previous studies have also found that salt stress leads to alterations in DNA methylation levels, and salinity tolerance is often attributed to DNA methylation status. For example, exposure to salt promotes DNA methylation in Mesembryanthemum crystallinum through the enhancement of DNA methyltransferase activity (Dyachenko et al., 2006). In addition, the genomes of some saline-tolerant cotton cultivars are hyper-methylated in comparison with the genomes of salinesusceptible cultivars (Wang et al., 2015a). Unlike in susceptible varieties, salt stress also increases DNA methylation in salt-tolerant wheat varieties (Zhong and Wang, 2007). However, salinity stress inconsistently affected the level of DNA methylation in two different canola genotypes (Marconi et al., 2013), and variations in salt tolerance among different rice varieties were unrelated to the pattern of DNA methylation induced by salt stress (Karan et al., 2012). A similar conclusion was reached when maize exhibited inconsistent DNA methylation change patterns resulting from cold, heat, and ultraviolet radiation (Eichten and Springer, 2015). Therefore, the findings of the current study are in agreement with those of previously published research.

Variations in DNA methylation in response to salinity treatment could be suitable epigenetic markers for plant breeding, and for the determination of salinity-tolerance mechanisms in alfalfa. The MSAP loci identified in this study can be used in marker-assisted selection. The sequencing results of some MSAP DNA fragments were similar to those of other MSAP and AFLP markers isolated from different plant species (Bove et al., 2005). However, they were not similar to genes that are involved in salinity tolerance in plants. Some MSAP products identified in this study were similar to genes cloned from symbiotic endophytic fungi and nitrogen-fixing bacteria, which indicates that at least some of the MSAP DNA generated was associated with bacterial and fungal genomes. The appearance and distribution of these genomes may vary, and could be influenced by the level of salinity in the rhizosphere. Endophytic bacteria may have a positive effect on salinity tolerance in plant species (Yaish et al., 2015a), including alfalfa.

Despite the fact that a global increase in DNA methylation may lead to gene repression, the DNA methyltransferase homolog genes tested here were upregulated by salinity treatment in alfalfa (Figure 8). This may partly explain the increase in DNA methylation levels detected by the MSAP and ELISA methods. DNA methyltransferase and demethylase gene expression in response to salt stress is genotype-dependent in rice (Oryza sativa L.) (Ferreira et al., 2015). A salt-tolerant 
rice variety only exhibited an increase in DNA demethylase gene expression, whereas a saltsusceptible variety exhibited an increase in the expression levels of both DNA demethylase and methyltransferase genes (Ferreira et al., 2015).

5-AzaC is widely used as a DNA methylation inhibition agent in plant research (Yaish et al., 2009). In this study, it was used to test the effect of reductions in DNA methylation on the salinity tolerance of alfalfa at the seedling stage. Despite the fact that this chemical may have some side effects on plant growth, we found that treatment with 5-AzaC led to a significant reduction in growth, as indicated by a reduction in seedling length and dry weight (Figure 7). This indicates that DNA methylation is necessary for salinity tolerance in alfalfa, and is consistent with the MSAP results. A reduction in DNA methylation could affect other epigenetic factors that control gene expression in response to stress, including posttransitional modifications of the N-terminal sequences of the histones, miRNA biogenesis, and the gene-targeting process (Yaish et al., 2009; Yaish et al., 2011). All of these modifications modulate gene expression in order to produce a healthy plant under saline conditions.

In conclusion, salinity stress induced varying degrees of alterations in DNA methylation levels in alfalfa landraces, which are probably important for salinity tolerance and adaptation. The determination of DNA methylation changes using the MSAP method may provide insights into the regulatory mechanism associated with salt-tolerance mechanisms in alfalfa. However, deciphering the epigenetic regulatory pathway that controls salinity tolerance requires the fine mapping of DNA methylation alterations across the genome in response to salinity stress.

\title{
Conflicts of interest
}

The authors declare no conflict of interest.

\section{ACKNOWLEDGMENTS}

\author{
University, Oman.
}

\section{REFERENCES}

Banasiak J, Biala W, Staszków A, Swarcewicz B, et al. (2013). A Medicago truncatula ABC transporter belonging to subfamily G modulates the level of isoflavonoids. J. Exp. Bot. 64: 1005-1015. http://dx.doi.org/10.1093/jxb/ers380

Bove J, Lucas P, Godin B, Ogé L, et al. (2005). Gene expression analysis by cDNA-AFLP highlights a set of new signaling networks and translational control during seed dormancy breaking in Nicotiana plumbaginifolia. Plant Mol. Biol. 57: 593612. http://dx.doi.org/10.1007/s11103-005-0953-8

Boyko A, Blevins T, Yao Y, Golubov A, et al. (2010). Transgenerational adaptation of Arabidopsis to stress requires DNA methylation and the function of Dicer-like proteins. PLoS One 5: e9514. http://dx.doi.org/10.1371/journal.pone.0009514

Chan SW-L, Henderson IR and Jacobsen SE (2005). Gardening the genome: DNA methylation in Arabidopsis thaliana. Nat. Rev. Genet. 6: 351-360. http://dx.doi.org/10.1038/nrg1601

Ci D, Song Y, Tian M and Zhang D (2015). Methylation of miRNA genes in the response to temperature stress in Populus simonii. Front. Plant Sci. 6: 921. http://dx.doi.org/10.3389/fpls.2015.00921

Dyachenko OV, Zakharchenko NS, Shevchuk TV, Bohnert HJ, et al. (2006). Effect of hypermethylation of CCWGG sequences in DNA of Mesembryanthemum crystallinum plants on their adaptation to salt stress. Biochemistry (Mosc.) 71: 461-465. http://dx.doi.org/10.1134/S000629790604016X

Eichten SR and Springer NM (2015). Minimal evidence for consistent changes in maize DNA methylation patterns following environmental stress. Front. Plant Sci. 6: 308. http://dx.doi.org/10.3389/fpls.2015.00308

Ferreira LJ, Azevedo V, Maroco J, Oliveira MM, et al. (2015). Salt tolerant and sensitive rice varieties display differential methylome flexibility under salt stress. PLoS One 10: e0124060. http://dx.doi.org/10.1371/journal.pone.0124060 
Garg R, Narayana Chevala V, Shankar R and Jain M (2015). Divergent DNA methylation patterns associated with gene expression in rice cultivars with contrasting drought and salinity stress response. Sci. Rep. 5: 14922. http://dx.doi. org/10.1038/srep14922

Halldén C, Nilsson NO, Rading IM and Säll T (1994). Evaluation of RFLP and RAPD markers in a comparison of Brassica napus breeding lines. Theor. Appl. Genet. 88: 123-128. http://dx.doi.org/10.1007/BF00222404

Henderson IR and Jacobsen SE (2007). Epigenetic inheritance in plants. Nature 447: 418-424. http://dx.doi.org/10.1038/ $\underline{\text { nature05917 }}$

Iwasaki M (2015). Chromatin resetting mechanisms preventing transgenerational inheritance of epigenetic states. Front. Plant Sci. 6: 380. http://dx.doi.org/10.3389/fpls.2015.00380

Jin B, Li Y and Robertson KD (2011). DNA methylation: superior or subordinate in the epigenetic hierarchy? Genes Cancer 2: 607-617. http://dx.doi.org/10.1177/1947601910393957

Kakutani T (2002). Epi-alleles in plants: inheritance of epigenetic information over generations. Plant Cell Physiol. 43: 11061111. http://dx.doi.org/10.1093/pcp/pcf131

Kakutani T, Kato M, Kinoshita T and Miura A (2004). Control of development and transposon movement by DNA methylation in Arabidopsis thaliana. Cold Spring Harb. Symp. Quant. Biol. 69: 139-143. http://dx.doi.org/10.1101/sqb.2004.69.139

Karan R, DeLeon T, Biradar H and Subudhi PK (2012). Salt stress induced variation in DNA methylation pattern and its influence on gene expression in contrasting rice genotypes. PLoS One 7: e40203. http://dx.doi.org/10.1371/journal.pone.0040203

Lindroth AM, Cao X, Jackson JP, Zilberman D, et al. (2001). Requirement of CHROMOMETHYLASE3 for maintenance of CpXpG methylation. Science 292: 2077-2080. http://dx.doi.org/10.1126/science.1059745

Lira-Medeiros CF, Parisod C, Fernandes RA, Mata CS, et al. (2010). Epigenetic variation in mangrove plants occurring in contrasting natural environment. PLoS One 5: e10326. http://dx.doi.org/10.1371/journal.pone.0010326

Marconi G, Pace R, Traini A, Raggi L, et al. (2013). Use of MSAP markers to analyse the effects of salt stress on DNA methylation in rapeseed (Brassica napus var. oleifera). PLoS One 8: e75597. http://dx.doi.org/10.1371/journal.pone.0075597

Monfreda C, Ramankutty N and Foley JA (2008). Farming the planet: 2. Geographic distribution of crop areas, yields, physiological types, and net primary production in the year 2000. Global Biogeochem. Cycles 22: GB1022 http://dx.doi. org/10.1029/2007GB002947.

Nye TM, Liò P and Gilks WR (2006). A novel algorithm and web-based tool for comparing two alternative phylogenetic trees. Bioinformatics 22: 117-119. http://dx.doi.org/10.1093/bioinformatics/bti720

Peel MD, Waldron BL, Jensen KB, Chatterton NJ, et al. (2004). Screening for salinity tolerance in alfalfa. Crop Sci. 44: 20492053. http://dx.doi.org/10.2135/cropsci2004.2049

Peraza-Echeverria S, Herrera-Valencia VA and Kay A (2001). Detection of DNA methylation changes in micropropagated banana plants using methylation-sensitive amplification polymorphism (MSAP). Plant Sci. 161: 359-367. http://dx.doi. org/10.1016/S0168-9452(01)00421-6

Postnikova OA, Shao J and Nemchinov LG (2013). Analysis of the alfalfa root transcriptome in response to salinity stress. Plant Cell Physiol. 54: 1041-1055. http://dx.doi.org/10.1093/pcp/pct056

Rahman MA, Alam I, Kim Y-G, Ahn N-Y, et al. (2015). Screening for salt-responsive proteins in two contrasting alfalfa cultivars using a comparative proteome approach. Plant Physiol. Biochem. 89: 112-122. http://dx.doi.org/10.1016/j. plaphy.2015.02.015

Rohlf FJ (1998). NTSYSpc: numerical taxonomy and multivariate analysis system. Version 2.02. http://www.exetersoftware. com/cat/ntsyspc/ntsyspc.html

Salmon A, Clotault J, Jenczewski E, Chable V, et al. (2008). Brassica oleracea displays a high level of DNA methylation polymorphism. Plant Sci. 174: 61-70. http://dx.doi.org/10.1016/j.plantsci.2007.09.012

Sreenivasulu N, Sopory SK and Kavi Kishor PB (2007). Deciphering the regulatory mechanisms of abiotic stress tolerance in plants by genomic approaches. Gene 388: 1-13. http://dx.doi.org/10.1016/j.gene.2006.10.009

Vos P, Hogers R, Bleeker M, Reijans M, et al. (1995). AFLP: a new technique for DNA fingerprinting. Nucleic Acids Res. 23: 4407-4414. http://dx.doi.org/10.1093/nar/23.21.4407

Wang B, Fu R, Zhang M, Ding Z, et al. (2015a). Analysis of methylation-sensitive amplified polymorphism in different cotton accessions under salt stress based on capillary electrophoresis. Genes Genomics 37: 713-724. http://dx.doi.org/10.1007/ $\underline{\text { s13258-015-0301-6 }}$

Wang W, Huang F, Qin Q, Zhao X, et al. (2015b). Comparative analysis of DNA methylation changes in two rice genotypes under salt stress and subsequent recovery. Biochem. Biophys. Res. Commun. 465: 790-796. http://dx.doi.org/10.1016/j. bbrc.2015.08.089

Yaish MW (2013). DNA methylation-associated epigenetic changes in stress tolerance of plants. In: Molecular stress physiology of plants (Rout GR and Das AB, eds.). Springer, Berlin, 427-440. http://dx.doi.org/10.1007/978-81-322-0807-5_17

Yaish MW (2015). Proline accumulation is a general response to abiotic stress in the date palm tree (Phoenix dactylifera L.). Genet. Mol. Res. 14: 9943-9950. http://dx.doi.org/10.4238/2015.August.19.30 
Yaish MW, Peng M and Rothstein SJ (2009). AtMBD9 modulates Arabidopsis development through the dual epigenetic pathways of DNA methylation and histone acetylation. Plant J. 59: 123-135. http://dx.doi.org/10.1111/j.1365-313X.2009.03860.x

Yaish MW, Colasanti $\mathrm{J}$ and Rothstein SJ (2011). The role of epigenetic processes in controlling flowering time in plants exposed to stress. J. Exp. Bot. 62: 3727-3735. http://dx.doi.org/10.1093/jxb/err177

Yaish MW, Peng M and Rothstein SJ (2014). Global DNA methylation analysis using methyl-sensitive amplification polymorphism (MSAP). Methods Mol. Biol. 1062: 285-298. http://dx.doi.org/10.1007/978-1-62703-580-4 16

Yaish MW, Antony I and Glick BR (2015a). Isolation and characterization of endophytic plant growth-promoting bacteria from date palm tree (Phoenix dactylifera L.) and their potential role in salinity tolerance. Antonie van Leeuwenhoek 107: 15191532. http://dx.doi.org/10.1007/s10482-015-0445-z

Yaish MW, Sunkar R, Zheng Y, Ji B, et al. (2015b). A genome-wide identification of the miRNAome in response to salinity stress in date palm (Phoenix dactylifera L.). Front. Plant Sci. 6: 946. http://dx.doi.org/10.3389/fpls.2015.00946

Zhong L and Wang J-B (2007). The role of DNA hypermethylation in salt resistance of Triticum aestivum L. J. Wuhan Bot. Res. 1: 019.

Zhong S, Fei Z, Chen YR, Zheng Y, et al. (2013). Single-base resolution methylomes of tomato fruit development reveal epigenome modifications associated with ripening. Nat. Biotechnol. 31: 154-159. http://dx.doi.org/10.1038/nbt.2462

\section{Supplementary material}

Table S1. Polymorphic methylation-sensitive amplified polymorphism bands produced using DNA extracted from the roots of untreated alfalfa plants (A) and plants watered with $20 \mathrm{dS} / \mathrm{M} \mathrm{NaCl}$ solution (B). http://www.geneticsmr.com/year2016/vol15-1/pdf/gmr8299 ts1.xls

Table S2. Similarity coefficients based on methylation-sensitive amplified polymorphism data generated using Hpall endonuclease and DNA extracted from the roots of untreated (A) and saline-treated (20 dS/m) plants (B) and Mspl endonuclease and DNA extracted from the roots of untreated (C) and saline-treated (20 dS/m) plants (D). http://www.geneticsmr.com/year2016/vol15-1/pdf/gmr8299 ts2.xls

Table S3. Classification of methylation-sensitive amplified polymorphism (MSAP) markers based on the results obtained using Hpall and Mspl endonucleases. The MSAP markers were classified as non-methylated (A), methylated $(B)$, or hemi-methylated $(C)$.

http://www.geneticsmr.com/year2016/vol15-1/pdf/gmr8299 ts3.xls

Figure S1. Effect of 5-azacytidine (5-AzaC) on alfalfa seedling length and dry weight when exposed to different levels of salinity $(50,100,200$, or $400 \mathrm{mM} \mathrm{NaCl})$ in the presence or absence of $50 \mu \mathrm{M} \mathrm{5-AzaC}$.

http://www.geneticsmr.com/year2016/vol15-1/pdf/gmr8299 supplementary.pdf 